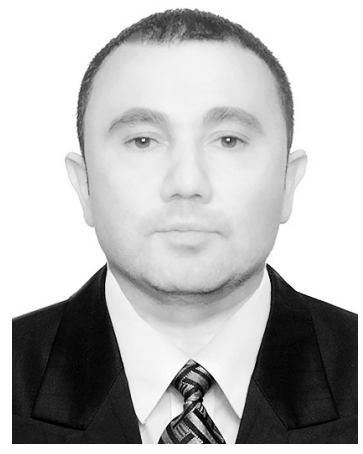

\title{
МІЖНАРОДНІ СТАНДАРТИ ЗДІЙСНЕННЯ АДВОКАТСЬКОї ДІЯЛЬНОСТІ
}

\author{
НАДЖАФЛІ Емін МУса огЛи - кандидат юридичних наук (доктор філософії), \\ адвокат (м. Харків, Україна)
}

DOI:10.32782/EP.2020.1.3

В статье осуществлено комплексное исследование международно-правовъих стандартов организачии и деятельности адвокатурви. Проведен анализ организачионнъих основ адвокатской деятельности зарубежньх стран. Международнъе стандарть осуществления адвокатской деятельности исследованъ на примере функиионирования института адвокатурь Бельгии, Великобритании, Греичии, Испании, Италии, Соединенных Штатов Америки, Франции, Швейцарии, Швеции и Японии. Отмечено, что несовершенством отличаются не только нормъ административного законодательства, а и отдельнъе гарантии принципа свободъ осуществления адвокатской деятельности и нормативные предписания, раскрьваюшие содержание тех или инъхх принципов осуществления адвокатской деятельности. Автором предложенъ отдельнъие пути совершенствования административного законодательства, определяющего основнъе приниипь адвокатской деятельности в Украине.

Ключевъе слова: адвокатская деятельность, адвокат, бормы приниипов осуществления адвокатской деятельности, источники принципов осуществления адвокатской деятельности, общие приниипь осуществления адвокатской деятельности, межотраслевъие принщипъ осуществления адвокатской деятельности, организачионно-бункииональнъге приниипъ осуществления адвокатской деятельности, международнъе стандартьл.

\section{Постановка проблеми}

На інститут адвокатури покладається низка важливих завдань пов'язаних із захистом прав і свобод осіб, представництвом їх інтересів у національних і міжнародних організаціях і установах різної спрямованості та рівня, включаючи судові установи. Події останніх років сприяли визначенню подальшого майбутнього для України як держави європейського зразка 3 високим рівнем суспільного життя та європейськими стандартами роботи державних і недержавних інституцій. Приведення роботи останніх до відповідності стандартам визнаним у всьому світі обумовило необхідність проведення низки значущих реформ у важливих сферах суспільного життя, зокрема ті, що стосуються сфери судочинства та організації діяльності суміжних правових інститутів. До яких відноситься і інститут адвокатури, удосконалення функціонування якого держава визнала одним із своїх завдань, передбачивши конкретні способи його виконання, насамперед шляхом прийняття ряду нормативно-правових актів і внесення змін до діючого законодавства, що регулює адвокатську діяльність. Таким чином, дослідження міжнародних стандартів адвокатської діяльності є актуальним та своєчасним [1, с.1-2].

\section{Стан дослідження}

Різні аспекти організації та діяльності інституту адвокатури розглядались багатьма науковцями різних галузей права, а саме А. В. Андрушко, Т. В. Бабчинська, С. В. Ва- 
сильєв, С. А. Деханов, Н. Ю. Голубєва, В. В. Городовенко, Р. А. Майданик, С. Ф. Сафулько, І. Я. Семенчук, зокрема адміністративному праві та процесі: В. Б. Авер'янов, В. В. Галунько, В. В. Гордєєв, В. К. Колпаков, А. Т. Комзюк, Н. Б. Писаренко, В. А. Сьоміна, Є. Ф. Шкребець. Такими вченими, як М. О. Баймуратов, М. В. Буроменський, Т. Б. Вільчик, О. Ф.Висоцький, I. В. Назаров, С. В. Шевчук, В. І. Шишкін та ін. завдяки використанню системного підходу здійснено спроби осмислення принципів, тенденцій, проблем і перспектив наближення правової системи України до права EC. Враховуючи стрімкий та динамічний розвиток реформаційних процесів в Україні, залишається актуальним питання подальшого дослідження та впровадження ефективної моделі адвокатської діяльності в механізмі забезпечення конституційних прав громадян, створення концептуальної моделі нових взаємовідносин адвокатури 3 органами державної влади, громадянським суспільством, встановлення їі ролі та значення у здійсненні справедливого судочинства.

Метою статті є комплексне дослідження організаційних засад інститутів адвокатури різних країн, а також міжнародних стандартів адвокатської діяльності.

\section{Виклад основного матеріалу}

Европейський вектор розвитку, який був визначений нашою країною та всім ії народом як перспективний обумовив необхідність приведення багатьох сфер суспільного життя до міжнародних стандартів якості, які визнаються в Европі і всьому світі. 3 цією метою Урядом України було започатковано та проведено ряд докорінних реформ у різних суспільно важливих сферах, наприклад правоохоронній або сфері охорони здоров'я. Проведення таких реформ як правило передбачає перебудову системи чи зміну засад їі функціонування межах кожної окремої сфери з метою удосконалення роботи останньої та підвищення якості та ефективності послуг, які надаються населенню.

Серед недоліків надання правової допомоги, які потребують усунення в Стратегії реформування судоустрою, судочинства та суміжних правових інститутів на 2015-2020 роки затвердженою указом Президента України від 20.05.2015 № 276/2015 були названі: «невідповідність формального статусу адвоката фактичним умовам здійснення адвокатської діяльності, в тому числі недосконалість практичного забезпечення прав адвоката і гарантій адвокатської діяльності; недосконала система формування органів адвокатського самоврядування та їх взаємодії, гарантій незалежності та належного виконання ними своїх функцій; недостатній рівень професійної підготовки адвокатів; неефективність дисциплінарного контролю і етичних стандартів в адвокатській діяльності; недосконалість бюджетного і фінансового управління в системі адвокатського самоврядування» [2].

Інститут адвокатури, умовно можна віднести до недержавних правоохоронних органів, метою створення та діяльності яких є охорона та захист прав, свобод, інтересів фізичних і юридичних осіб, та як наслідок, їх поновлення. О. Г. Яновська наголошує на тому, що «серед усіх юридичних засобів захисту прав людини чільне місце належить адвокатурі. Ї̈̈ фундаментальним призначенням є захист прав людини і саме тому необхідне досконале функціовання цього надзвичайно важливого правозабезпечувального інституту. Реальна здійсненність і надійна захищеність прав людини є найвищим критерієм прогресивності адвокатури» [3, с. 159].

3 огляду на важливу роль даного інституту, було прийнято рішення про необхідність підвищення ефективності його діяльності шляхом зміни та удосконалення основних засад його існування. Останне стає можливим за допомогою прийняття ряду нормативно-правових актів які частково чи повністю змінюють вказані засади на законодавчому рівні, так було прийнято Закон України «Про внесення змін до Конституції України (щодо правосуддя)» [4], яким внесено ряд суттєвих законодавчих змін, а також Президентом України внесено до Верховної Ради України проект Закону про адвокатуру та адвокатську діяльність № 9055 від 06.09.2018 (на сьогодні він включений для порядку денного) [5]. Проте реформування 


\section{Адміністративне право}

інституту адвокатури не обмежується прийняттям двох правових актів, а являє собою складний довготривалий кропіткий процес груп фахівців у галузі права, який не може бути проходити ізольовано від дослідження зарубіжного досвіду здійснення адвокатської діяльності та визначення міжнародних стандартів останньої за для визначення можливих перспектив подальшої імплементації. При цьому слід враховувати, що міжнародні стандарти здійснення адвокатської діяльності - це «досить умовна реальність, позаяк ми не маємо «світових стандартів адвокатури», так само як і не існуе «світової адвокатури»». $\mathrm{E}$ низка, міжнародних, прийнятих на досить високому, однак не всесвітньому рівні актів, які можна віднести до тих, що формують ті самі «світові стандарти адвокатури», але це не $\epsilon$ те, що прийнято «всім світом»» [6, с. 245]. В такому контексті пріоритетним є дослідження саме європейських стандартів, які є спільними для усіх країн-членів Европейського союзу, а також вивчення досвіду роботи адвокатів вказаних країн.

Вагомим внеском в утвердження уніфікованих європейських стандартів повинно стати прийняття Европейської конвенції «Про професію адвоката» (European Convention on the Profession of Lawyer) необхідність розроблення якої була обгрунтована в Рекомендації № 2121 (2018) Парламентської асамблеї Ради Европи (ПАРЕ) щодо розробки Европейської конвенції щодо професії адвоката від 25.01.2018 [7]. Передбачається, що даний документ, на відміну від інших рекомендацій і директив, матиме статус «обов'язковий для виконання», а тому матиме чіткий і ясний механізм забезпечення гарантій адвокатської діяльності та встановить реальний контроль за дотриманням закріплених положень. Прийняття даного документу обумовлено обставинами пов'язаними 3 порушенням державами в особі іï органів національних гарантій адвокатської діяльності, зокрема: «неналежне розслідування фактів вбивств, спричинення тілесних пошкоджень, зникнень адвокатів або знищення їх майна, допити адвокатів в якості свідків у справах їхніх клієнтів, використання дисциплінарного провадження як методу тиску щодо адвокатів, порушення адвокатської таємниці в ході проведення обшуків і виїмок. Крім того, відсутній ефективний механізм контролю за втручанням держав в діяльність адвокатів в країнах» [8].

Вважаючи цей напрям роботи вкрай актуальним дослідження міжнародних стандартів здійснення адвокатської діяльності стало одним із завдань нашої наукової роботи, але зважаючи на вимоги, що висуваються до останньої щодо обсягу даного виду робіт, ми не зможемо приділити достатню увагу всім міжнародним стандартам і вимогам. Тому, обмежимось коротким оглядом зарубіжного досвіду організації діяльності адвокатури та окремими засади встановленими на міжнародному рівні.

Під міжнародними стандартами в сфері здійснення адвокатської діяльності, на думку ᄉ. І. Бойко, необхідно розуміти «міжнародні стандарти професійної діяльності адвоката визнаються загальні деонтологічні вимоги, яким мають слідувати адвокати, незалежно від кордонів (державних, галузевих та ін.) здійснення своєї професіональної діяльності в цілях гуманізації суспільних відносин, утвердження законності та правопорядку в кожній країні» [9, с. 162]. Проте, спершу вважаємо необхідним розглянути організаційні засади та окремі аспекти функціонування інституту адвокатури в різних зарубіжних країнах. Наприклад, у Великобританії функції адвокатури здебільше виконують баристери (barristers), при цьому юридичну професію представляють дві окремі великі групи: соліситори (solicitors) та баристери (barristers). Перші є представниками різних установ i організацій: «вони є кваліфікованими сторонами у судових процесах і можуть виступати як сторони в усіх судах. Однак вони не мають право аудієнції в усіх судах. Незалежно практикуючі barristers отримують справи шляхом передачі на розгляд, тобто, вони не приймають судові доручення безпосередньо від клієнтів; вони отримують судові доручення, як правило, від solicitors. Вони здійснюють право аудієнції у будь-якому суді і мають виключне право аудієнції у вищих судах» [10,с. 9-10]. Окрім того, баристери можуть надавати юридичну допомогу автономно, тобто їх діяльність грунтується на 
принципі незалежності. Схожа модель діє і в інших країнах, таких як Сполучені Штати Америки (де всі адвокати об'єднуються в одну асоціацію за територіальним принципом, тобто асоціацію юристів штату на території якого буде провадитись їх діяльність), Німеччина, Франція чи Японія де фактично «унеможливлено участь адвоката як у суді, так і на досудовому слідстві, якщо він не має відповідного статусу належності до однієї 3 адвокатських корпорацій незалежно від бажання обвинуваченого чи підсудного» [11, c. 100].

Розглянемо таку модель більш детально на прикладі адвокатури Італії, остання здійснюється за принципом приналежності адвокатів до тієї чи іншої організації, компетенція якої поширюється на визначену територію округу, тобто має місце суворе додержання територіального принципу здійснення адвокатської діяльності, яку очолює Рада адвокатів і прокурорів. Остання діє на засадах самостійності та незалежності, а їі основним завданням є захист прав i професійних інтересів адвокатів. До компетенції Ради адвокатів і прокурорів віднесено вирішення наступних питань: «здійснення реєстрації нових членів, перевід адвокатів 3 одного міста у інше, підтримання дисципліни та порядку, проведення культурних й спортивних заходів; висунення своїх членів в Національну спілку адвокатів, що є загальнореспубліканською організацією адвокатів» $[12$, с. 131$]$.

Для кожної асоціації адвокатів встановлена гранична чисельність осіб, які можуть входити до конкретної асоціації, воно може відрізнятись в залежності від кількості адвокатів, що мешкають і провадять власну професійну діяльність на його території, проте не повинна перевищувати п'ятнадцяти осіб.

Серед множинності італійських адвокатських асоціації існує ще одна: їі члени мають право здійснювати юридичну практику в судових відомствах вищої ланки, як от Конституційному суду Італійської Республіки чи Касаційному суду Італії, одною 3 основних умов приєднання до зазначеної асоціації є восьмирічний стаж роботи адвокатом. Корпорації оказують значний вплив на юридичну практику країни та користуються пова- гою серед населення, люди впевнені в професійних і морально-етичних якостях осіб до яких вони звертаються за допомогою, а тому адвокати, які в подальшому стають політичними та суспільними діячами користуються популярністю серед місцевого населення Італії. Приналежність адвоката до тієї чи іншої професійної асоціації виступає гарантією його професіоналізму, стабільності та надійності. В Італії та ряді вище перелічених країн (Великобританії, Франції, Японії) в окремих видах судових засідань можуть брати участь лише деякі з тих адвокатів, якими виконується умова щодо приналежності до конкретної асоціації

Умови допуску до адвокатської професії теж відрізняється в кожній окремій країні від жорстких до більш жорстких. Так, в Сполучених Штатах Америки вимоги та умови, які необхідно виконати особі, що претендує на право заняття адвокатською діяльністю визначає переважно Верховними судами штатів, а «спеціальні комісії, які розглядають заяви про допуск до адвокатської практики, найчастіше працюють під контролем суду або губернатора штату. У багатьох штатах дисциплінарне провадження щодо адвоката здійснюється за участю судових інстанцій. У цих випадках рішення органів адвокатського самоврядування носять рекомендаційний характер, а остаточне рішення приймається окружним судом. У ряді штатів дисциплінарне провадження щодо адвоката передається для остаточного рішення не суду, а генеральному атторнею або місцевому прокурору» [13, с. 253]. Сполучені Iтати Америки не єдина країна в якій органи судової влади поряд із судами мають повноваження не тільки стосовно формування корпусу адвокатів (адвокатських асоціацій), вирішення та розгляду щодо них дисциплінарних проваджень і питань отримання гонорарів, у Великобританії, Німеччині та Франції теж активно використовується подібна практика. С.А. Деханов зауважує, що «у країнах $\mathrm{EC}$ цей контроль має зовнішній характер і передбачає втручання держави у внутрішні справи органів самоврядування адвокатурою» [13, 252-253].

Підходи, щодо вирішення питань про надання правової допомоги адвокатами 


\section{Адміністративне право}

поза межами країни атестації та отримання документа (свідоцтва, посвідчення), що надає право на провадження адвокатської діяльності, теж вкрай різноманітні. Наприклад, Великобританія притримувалась погляду, який фактично не створював перешкод і обмежень для діяльності «іноземних адвокатів», у той час коли Франція зайняла протилежну позицію мотивуючи це невідповідністю суспільним інтересам і цінностям і засадам адвокатської діяльності: «зазначення титулу, отриманого у своїй країні, створювало у клієнта хибну уяву про те, що адвокат вирішуватиме його справу з позицій права його країни, що фактично неможливо, а також, що такий адвокат буде часто плутати галузі права. Франція наполягала на тому, щоб адвокат міг якнайшвидше використовувати титул приймаючої держави» [14, с. 131-132]. Парадокс полягав у тому, що такі обставини сприяли виникненню ситуації, коли значна кількість адвокатів виявили бажання провадити власну професійну діяльність на базі французької адвокатури, а позиція самої держави була неоднозначно оцінена Европейською комісією.

Відрізняються власними специфічними рисами також організація роботи адвокатських самоврядувань у країнах Европейського Союзу така відмінність наглядно продемонстрована в дослідженні М. В. Руденко щодо організаційних форм адвокатської діяльності у зарубіжних країнах, а точніше організації діяльності адвокатського самоврядування в різних країнах. Усі органи адвокатських самоврядувань було типологізовано наступним чином. Перша, класична модель передбачає обов'язкову належність адвокатів до відповідної палати адвокатів (Бельгія, Іспанія, Франція, Італія, Греція), останні функціонують на підставі територіального принципу та «об'єднують усіх адвокатів внесених до списку на території тієї чи іншої федеральної землі Юрисдикція кожної палати адвокатів поширюється на територію тієї федеральної землі для якої ця палата була заснована, а також на всіх адвокатів, які внесені до списку цієї палати адвокатів» [15, с. 168]. До другої групи зараховані країни Швеції та Швейцарії, де адвокатське самоврядування реалізується через спеціальні асоціації чи професійні спілки. Наступна модель передбачає управління інститутом адвокатури безпосередньо через судові органи та інші професійно-юридичні спільноти, наприклад у Великобританії.

На ряду з місцевими асоціаціями та іншими об'єднаннями адвокатів у кожній державі сьогодні активно провадять власну діяльність «правничі інституції, які репрезентують у країнах юристів у цілому й адвокатів, зокрема. Однією з них є Рада адвокатур і правничих об'єднань EC (Council of the Bars and Law Societies of the European Union), утворена у 1960 р. Ця інституція об’ єднує 28 адвокатур (Свропи): Австрії, Англії, Бельгії, Болгарії, Греції, Естонії, Ірландії, Іспанії, Італії, Аатвії, Аитви, Аюксембургу, Македонії, Мальти, Нідерландів, Німеччини, Польщі, Португалії, Румунії, Словаччини, Словенії, Угорщини, Франції, Хорватії, Чехії, Швейцарії та ін.» [14, с. 133]. Зазначена організація об'єднує усіх юристів, зокрема тих які провадять адвокатську діяльність, координуючи, представляючи та захищаючи їх роботу, проводячи конференції, наради, консультації з питань юридичної практики, аналізуючи здійснення адвокатами власної професійної діяльності 3 метою подальшої розробки рекомендацій щодо іï удосконалення, безпосередньо вирішує проблеми, що виникають у фахівців під час здійснення ними своєї професійної діяльності як на прикладному так і на теоретичному рівнях.

Таким чином, національне законодавство, яке регулює адвокатську діяльність у контексті дослідження основних засад функціонування адвокатури зарубіжних країн таких як: Бельгія, Великобританія, Греція, Іспанія, Італія, Сполучені Штати Америки, Франція, Швейцарія, Швеція та Японія, виглядає досить прогресивним. Інститут адвокатури України сьогодні вміщує в себе найкращі традиції та практичні положення організаційно-функціонального характеру різних країн світу. Такого висновку можна дійти, щонайменше через тезу щодо повноти реалізації всесвітніх стандартів адвокатури, зокрема принципів свободи та незалежності здійснення адвокатської діяльності. Оскільки в більшості країн Европейського Союзу ці фундаментальні засади не зна- 
йшли свого повного втілення, щонайменше через встановлення обов'язку щодо приналежності адвокатів до тих чи інших асоціацій. Втім, вже на даному етапі дослідження ми можемо констатувати, що не дивлячись на прогресивні положення національного законодавства залишається значна кількість проблем пов'язаних із встановленням і приведенням у дію механізмів їх реалізації, насамперед у сфері реалізації гарантій адвокатської діяльності та роботи органів адвокатського самоврядування, яке як показує практичний досвід не достатньо ефективно виконує поставлені перед ними завдання.

3 метою більш детального дослідження міжнародних стандартів здійснення адвокатської діяльності ми вважаємо необхідним розглянути окремі приписи міжнародних документів, які на сьогодні не знайшли відображення чи належного відображення в національному законодавстві, що регулює адвокатську діяльність, але є не менш важливими за всі інші їі засади. В п. 4 Рекомендації № R (2000) 21 Комітету Міністрів Ради Европи державам-членам про свободу професійної діяльності адвокатів ухваленої Комітетом Міністрів Ради Европи (на 727 засіданні заступників міністрів) від 25.10.2000 вказано: «адвокатські колегії та інші професійні об'єднання адвокатів слід заохочувати до забезпечення незалежності адвокатів i, окрім іншого, до: а) безстрашного відстоювання і підтримки справи правосуддя; b) захисту ролі адвокатів у суспільстві та, зокрема, обстоювання їхньої честі, гідності та доброчесності; с) сприяння участі адвокатів у програмах, які забезпечують доступ до правосуддя особам в економічно несприятливому становищі, зокрема наданню адвокатами безоплатної правової допомоги та юридичних консультацій; d) сприяння реформам законодавства, підтримки таких реформ і обговорення чинного чи запропонованого законодавства; е) сприяння добробуту представників професії та допомоги їм або членам їхніх сімей, якщо того вимагають обставини; f) співпраці з адвокатами 3 інших країн, зокрема беручи до уваги роботу міжнародних організацій адвокатів і міжнародних міжурядових чи недержавних організацій; g) просування якомога вищих професійних стандартів компетентності адвокатів і забезпечення додержання адвокатами стандартів поведінки та дисципліни» [16]. Ряд з пунктів вказаних у наведеній рекомендації, а саме щодо сприяння підвищення рівня престижу адвокатської професії та добробуту адвокатів і членів їх сімей, а також запровадження та утвердження найвищих стандартів і професійної дисципліни.

Досить актуальну та раціональну норму передбачено в п. 15 Міжнародного кодексу етики прийнятим Міжнародною асоціацією юристів у 1988 році: «у грошових справах юристи повинні бути найбільш пунктуальними і уважними. Їм ніколи не слід змішувати кошти інших осіб зі своїми власними, i їм завжди слід бути в змозі повернути гроші, які вони тримають для інших осіб. Вони не повинні утримувати у себе гроші, які вони отримують для своїх клієнтів, довше, ніж це абсолютно необхідно» $[17$, с. 5].

Дане положення стосується безпосередньої організації власної професійної діяльності кожним окремим юристом, зокрема адвокатом і частково співвідноситься 3 п.п. “д» п. 3 Рекомендації № R (2000) 21 Комітету Міністрів Ради Европи державамчленам про свободу професійної діяльності адвокатів ухваленої Комітетом Міністрів Ради Европи (на 727 засіданні заступників міністрів) від 25.10.2000, де серед головних обов'язків перед власними клієнтами були вказані наступні: «а) консультування клієнтів 3 питання їх юридичних прав i обов'язків, а також можливого результату i наслідків справи, включаючи фінансові витрати; б) спробу вирішити справу перш за все мирним шляхом; в) порушення судового позову з метою захисту, поваги і забезпечення прав і інтересів своїх клієнтів; г) уникнення конфліктів; д) не брати на себе більше роботи, ніж вони в змозі виконати» [16]. 3 зазначеного випливає, що кожний адвокат повинен планувати та організовувати свою роботу для того, що б уникнути тієї ситуації, коли надмірне навантаження призведе до неякісного виконання вищевказаних обов'язків перед клієнтами. Окрім того, у поводженні 3 грошовими коштами та гонорарами адвокати повинні бути обач- 


\section{Адміністративне право}

ливими та обережними для того, що б мати можливість у разі необхідності повернути кошти клієнту та уникнути плутанини останніх із власними коштами.

\section{Висновки}

Таким чином, сьогодні напевно, як ніколи раніше, національні засади діяльності адвокатури наближені до всесвітніх стандартів функціонування інституту адвокатури та втілюють всі основоположні принципи закріплені в міжнародних документах. Проте, залишається ряд питань, які потребують уточнення, зокрема вони пов'язані 3 механізмом забезпечення та втілення даних принципів, тому що закріплення їх на законодавчому рівні недостатньо. Не менш важливими питаннями, що потребують нагального вирішення також залишається гарантування свободи та здійснення адвокатської діяльності та відповідного принципу, яким закріплена дана засада.

\section{入ітература}

1. Наджафлі Е.М. Принципи здійснення адвокатської діяльності в Україні: адміністративно-правовий аспект. : автореф. дисс. ... д-ра. філософії : 12.00.07. ДВНЗ «Київський національний економічний університет імені Вадима Гетьмана» МОН України, Київ, 2019. 19 с.

2. Про затвердження Порядку ведення Єдиного державного реєстру судових рішень : рішення Вищої ради правосуддя 19.04.2018 № 1200/0/15-18 // БД «Законодавство України» / ВР України. URL: https:// zakon.rada.gov.ua/rada/show/v1200910-18.

3. Дисертація на здобуття наукового ступеня кандидата юридичних наук за спеціальністю 12.00.07 Яновська О. Г. Стандартизація адвокатської діяльності: вимога сьогодення. Вісник кримінального судочинства. 2015. № 1. С. 157-162.

4. Про внесення змін до Конституції України (щодо правосуддя) : закон України від 02.06.2016 № 1401-VIII. Відомості Верховної Ради Украӥни. 2016. № 28. Ст. 532.

5. Проект Закону про адвокатуру та адвокатську діяльність № 9055 від 06.09.2018 // БД «Законодавство України» / ВР України.
URL: $\quad$ http://w1.c1.rada.gov.ua/pls/zweb2/ webproc4 1 ? pf3511 $=64557$.

6. Сафулько С.Ф. До питання реалізації світових стандартів в адвокатури в українській практиці. Право України. 2011. №10. С. 242-246.

7. Свропейська конвенція про правничу професію 2020 року. CCBE Info. 2018. № 71. URL: http://unba.org.ua/assets/uploads/ d12281c56cdc3e0de93d file.pdf.

8. Профстандарти адвокатури: міжнародний погляд // Портал Yur-Gazeta. com (Юридична Газета). URL: http://yurgazeta.com/publications/practice/inshe/profstandarti-advokaturi-mizhnarodniy-poglyad. $\underline{\text { html. }}$.

9. Бойко $\lambda$. I. Міжнародні стандарти дисциплінарної відповідальності адвокатів. Юридична наука. 2015. № 4. С. 161-166.

10. Стажування для набуття особою права на здійснення адвокатської діяльності в країнах 6С. (інформаційна довідка, підготовлена Європейським інформаційнодослідницьким центром на запит народного депутата України). 12 c. URL: http://euinfocenter.rada.gov.ua/uploads/documents/28987.pdf.

11. Рабовська В. Я. Окремі питання принципів діяльності адвокатури в Україні. Цивілістична прочесуальна думка. 2015. № 1. C. $98-101$.

12. Святоцький О. Д., Медведчук В. В. Адвокатура історія і сучасність. К : Ін Юре, 1997. $320 \mathrm{c}$.

13. Деханов С. А. Адвокатура в Западной Европе: опыт и современное состояние : дисс. ... д-ра. юрид. наук : 12.00.11. М., 2011. 383 c.

14. Семенюк I. Я. Моральні засади діяльності інституту адвокатури: теоретикоправовий аспект : дис. ... канд. юрид. наук : 12.00.01. Аьвів, 2016. 240 с.

15. Руденко М. В. Організаційні форми адвокатської діяльності у країнах Европи (Німеччина, Швеція, Австрія). Форум права. 2016. № 2. C. 168-174. URL: http://nbuv.gov. ua/UJRN/FP index.htm 2016227.

16. Рекомендація № R (2000) 21 Комітету Ради Міністрів Европи державам-членам про свободу професійноїдіяльності адвокатів (ухвалена на 727 засіданні заступників 


\section{АНОТАЦІЯ}

У статті здійснено комплексне дослідження міжнародно-правових стандартів організацї та діяльності адвокатури. Проведено аналіз організаційних засад адвокатсъкої діяльності зарубіжних країн. Міжнародні стандарти здійснення адвокатсъкої діяльності досліджені на прикладі бункціонування інституту адвокатури Бельгї, Великобританї, Греиї, Іспанї, Італї, Сполучених Штатів Америки, Франииї, Швейцарій, Швециї та Японії. Відзначено, що недосконалістю відрізняються не тільки норми адміністративного законодавства, а й окремі гарантиї принщипу свободи здійснення адвокатсъкої діяльності та нормативні приписи, що розкривають зміст тих або інших приниипів здійснення адвокатсъкої діяльності.

Зроблено висновок, що національні засади діяльності адвокатури наближені до всесвітніх стандартів функиіонування інституту адвокатури та втілюють всі основоположні принципи закріплені в міжнародних документах. Проте, залишається ряд питань, які потребують уточнення, зокрема вони пов'язані змеханізмом забезпечення та втілення даних приниипів, тому що закріплення їх на законодавчому рівні недостатнъо. Не мени важливою проблемою, що потребує нагального вирішення також залишається гарантування свободи та здійснення адвокатської діяльності та відповідного принципу, яким закріплена дана засада. Автором запропоновані окремі шляхи вдосконалення адміністративного законодавства, що визначає основні принципи адвокатсъкої діяльності в Украйні.

Ключові слова: адвокатська діяльність, адвокат, борми приниипів здійснення адвокатської діяльності, джерела приниипів здійснення адвокатсъкої діяльності, загальні принципи здійснення адвокатсъкої діяльності, міжгалузеві принципи здійснення адвокатсъкої діяльності, організачійно-ббункиіональні принщипи здійснення адвокатсъкої діяльності, міжнародні стандарти.

міністрів 25.10.2000). URL: https://supreme. court.gov.ua/userfiles/R_2000_21_2000_10_25. pdf.

\section{SUMMARY}

The article is focused on the analysis of international and legal standards of the Bar's organization and activity. The author has comprehensively analyzed the organizational principles of the advocacy activity of foreign countries.

International standards for the implementation of advocacy are studied on the example of the functioning of the institute of advocacy of Belgium, Great Britain, Greece, Spain, Italy, the United States of America, France, Switzerland, Sweden and Japan. It was noted that not only norms of administrative legislation differ in imperfections, but also separate guarantees of the principle of freedom to practice law and normative regulations that reveal the content of these or other principles of the practice of law. Separate ways of improving the administrative legislation defining the basic principles of advocacy in Ukraine are also proposed.

It has been concluded that the national principles of the Bar' activity are close to the world standards of the Bar Institution's functioning and embody all the fundamental principles enshrined in international documents. However, there is a number of issues that need to be clarified, in particular they are related to the mechanism for ensuring and implementing these principles, since it is insufficient to enshrine them at the legislative level. Guaranteeing freedom and implementation of the advocacy activity, as well as the relevant principle that enshrines this principle is equally important problem that needs to be solved. The author has offered some ways for improving administrative legislation, which defines the basic principles of the advocacy activity in Ukraine.

Key words: advocacy, attorney, forms of principles for the implementation of advocacy, sources of principles for the implementation of advocacy, general principles for the implementation of advocacy, inter-sectoral principles for the implementation of advocacy, organizational and functional principles of advocacy, international standards.

17. Матат А. В. Принципи права в системі джерел конституційного права України (від ідеї до самостійного джерела). Право і громадянсъке суспільство. 2017. №1-2. C. 4-24. 